\title{
Serum Biochemical Investigations on Retained Placenta in Egyptian Buffaloes
}

\section{Mervat Hassan ${ }^{1}$, Nani Nasreldin ${ }^{2}$, Marwa El-Zeftawy ${ }^{3,4 *}$}

${ }^{1}$ Theriogenology Department, Faculty of Veterinary Medicine, The New Valley University, New Valley, Egypt; ${ }^{2} \mathrm{~Pa}-$ thology and Clinical Pathology Department, Faculty of Veterinary Medicine, The Nerw Valley University, New Valley, Egypt; ${ }^{3}$ Biochemistry Department, Faculty of Veterinary Medicine, The New Valley University, New Valley, Egypt; ${ }^{4}$ Biological Screening and Preclinical Trial Lab, Biochemistry Department, Faculty of Science, Alexandria University, Alexandria, Egypt.

\begin{abstract}
Retained placenta (RP) is one of the reproductive syndromes that occurs in dairy buffaloes where fetal membranes fail to be expelled during 12-hours following parturition. RP cause several economic losses as a result of reduced milk production and infertility resulting prolonged calving interval in affected animals. The purpose of this research was to investigate some proteins alterations at molecular level in relation to metabolic, oxidative, hormonal and immunological changes in Egyptian buffaloes exposed to RP compared to others without RP and non-calved ones. Vaginal examination and rectal palpation were performed to inspect any abnormalities. Blood glucose (BG), lipid and protein profiles, alanine aminotransferase (ALT), aspartate aminotransferase (AST), urea and creatinine levels were estimated by biochemical techniques. Some macro and micro-minerals concentration were also analyzed. The antioxidant defense system was studied via measuring nitric oxide (NO), malonaldehyde (MDA) and reduced glutathione (GSH) concentrations and total antioxidant capacity (TAC) and specific activity of superoxide dismutase (SOD). Further, progesteron $\left(\mathrm{P}_{4}\right)$ and $17 \beta$-estradiol $\left(\mathrm{E}_{2}\right)$ concentration were explored. Different protein amount percentage was determined using SDS-PAGE electrophoresis. As well as, gene expression of interleukin-1beta (IL-1 $\beta$ ) and interleukin-6 (IL-6) was evaluated. In RP group, the obtained data exhibited reduction of BG and lipid profile with exception of very low density lipoprotein. Likewise, alterations of protein were noticed including elevation of globulin and diminishing of albumin. Pro-oxidant parameters (MDA and NO) were elevated; whereas, antioxidant factors (TAC, GSH and SOD) were declined. Moreover, urea concentration, ALT and AST activities were significantly increased, while there wasn't change in creatinine level. At hormonal level, a reduction of $\mathrm{E}_{2}$ and elevation of $\mathrm{P}_{4}$ were noticed and the gene expression of both IL-1 $\beta$ and IL- 6 was declined. From the obtained results we can conclude that $\mathrm{RP}$ accompanied by low immunity and oxidative stress which directly affect metabolic and hormonal conditions of the animals and it influences proteins amount in the body which is responsible for the body defense.
\end{abstract}

Keywords | Retained placenta, Egyptian buffaloes, Oxidative stress, Inflammation, Cytokines.

Received | September 14, 2019; Accepted | December 23, 2019; Published | January 03, 2020

*Correspondence | Marwa El-Zeftawy, Biochemistry Department, Faculty of Veterinary Medicine, The New Valley University, New Valley, Egypt.; Email: marwa@vetnv.au.edu.eg; marwa_3_1983@yahoo.com

Citation | Hassan M, Nasreldin N, El-Zeftawy M (2020). Serum biochemical investigations on retained placenta in Egyptian buffaloes. Adv. Anim. Vet. Sci. 8(1): $67-76$

DOI | http://dx.doi.org/10.17582/journal.aavs/2020/8.1.67.76

ISSN (Online) | 2307-8316; ISSN (Print) | 2309-3331

Copyright $\odot 2020$ El-Zeftawy et al. This is an open access article distributed under the Creative Commons Attribution License, which permits unrestricted use, distribution, and reproduction in any medium, provided the original work is properly cited.

\section{INTRODUCTION}

$\mathrm{B}$ uffaloes constitute a highly economic importance as they participate in meat and milk production in several developing countries including Egypt. Reproductive disorders such as delayed puberty onset, poor estrus cycle, dystocia, metritis and retained placenta (RP) have a direct negative impact on the reproductive efficiency in buffaloes (Fareed et al., 2017).

Placenta is a temporary endocrine gland where part of it develops from maternal uterine tissues while the other part develops from blastocyst which forms the fetus. In normal condition, placenta is expelled within 12-hours after deliv- 
ery (Tucho and Ahmed, 2017). The main role of placenta is focused on nutrients and oxygen transfer from dam to the embryo, in addition it secretes many hormones to support pregnancy and fetal growth (Burton and Fowden, 2015).

$\mathrm{RP}$ is a pathological reproductive condition results due to failure of the expulsion of all or part of the placenta or fetal membranes after delivery through 12 hours (Tucho and Ahmed, 2017). The fundamental causes of RP fluctuated from twine birth, nutritional deficiency, low immunity and environmental and hormonal causes (Pontes et al., 2015). $\mathrm{RP}$ produces several harmful effects inside reproductive organs of animals because it allows growth of microorganisms inside the uterus causing uterine inflammation (Kimura et al., 2002). In addition, fever, weight loss and reduction of milk yield are common adverse effects of $\mathrm{RP}$ syndrome and in severe cases animal death may occur due to hemorrhage (Tagesu, 2018). Other risk factors associated with RP include delayed uterine involution, ovarian cystic degeneration, chronic endometritis, pyometra and fertility reduction (Ganaie et al., 2018).

The idea of current work came from the increased rates of multiple gynecological problems in Egyptian farms which may lead to livestock economic losses in the future and one of those problems is RP syndrome. Hence studying some metabolic pathways of RP may be a helpful tool to treat the condition before its onset. So, this study was directed to evaluate the adverse effect of delayed placental expulsion (RP) 24-hours post parturition in Egyptian buffaloes via the investigation of some biochemical and immunological parameters in comparison with non-retained (NRP) placenta group and heifers (HEF) that did not yet give birth to a calf.

\section{MATERIAL AND METHODS}

\section{Reagents and Chemicals}

Kits of total protein (TP), blood glucose (BG), total cholesterol (TC), triacylglycerol (TG) and high density lipoprotein-cholesterol (HDL-c) were got from Diamond (Egypt), photometric albumin, urea and creatinine and kinetic alanine aminotransferase (ALT) and aspartate aminotransferase (AST) kits were purchased from Human Co. (Germany). Total antioxidant capacity (TAC) kit was bought from Biodiagnostic Co. (Egypt). As well as kits of calcium $\left(\mathrm{Ca}^{2+}\right)$, magnesium $\left(\mathrm{Mg}^{2+}\right)$, copper $\left(\mathrm{Cu}^{2+}\right)$, zinc $\left(\mathrm{Zn}^{2+}\right)$ and total iron (TF) were obtained from Spectrum Co. (Germany).

Protein and deoxy ribonucleic acid (DNA) ladder and complementary deoxy ribonucleic acid (cDNA) kit were purchased from Biovision (USA). Serum ribonucleic acid (RNA) purification and Maxime reverse transcription
(RT) Premix Kits were got from NORGEN (Canada) and INtRon Biotechnology (INC). Enzyme linked immuno assay (ELISA) kits of progesterone $\left(\mathrm{P}_{4}\right)$ and $17 \beta$-estradiol $\left(E_{2}\right)$ were obtained from DiaMetra (Italy).

Acrylamide, sodium dodecyl sulfate (SDS), B-mercaptoethanol, thiobarbituric acid, trichloroacetic acid, sodium nitroprusside, sulfanilamide, N-naphthylethylenediamine dihydrochloride, 5'-5'-dithio bisnitrobenzoic acid, reduced glutathione (GSH) standard, Tris $\mathrm{HCl}$, superoxide dismutase (SOD) standard, pyrogallol, agrose, boric acid, ethidium bromide, bromophenol blue and other organic solvents were purchased from SigmaAldrich Chemical Co. (USA). Diethylene triaminopenta acetic acid and 5-sulfosalicylic acid dehydrate were obtained from ACROS CO. (USA, Belgium) and Nour Resh,shark Co. (Egypt) respectively.

\section{Study Design, Gynecological Examination and} Blood Samples Collection

The study was conducted on 3 dairy farms at Assiut province, Egypt (Arab orders center Abnob, village Bani Mor and village bathroom of Abnob center) from 2016 till 2017. The climatic temperature of the farm ranged between $12^{\circ} \mathrm{C}$ in winter and $45^{\circ} \mathrm{C}$ in summer months and relative humidity $41-85 \%$. Buffaloes were fed ad-libitum seasonal green food and concentrate mixture. The study was conducted on non-parturated buffaloes which named HEF and others subjected to third time of parturition and there wasn't any interference during the pregnancy or parturition. Gynecological inspection via rectal palpation and vaginal examination post parturition was performed for all calved buffaloes and time of placenta expulsion was observed and it was reported that some buffaloes weren't expelled their placenta within 12 hour. Hence, our study was performed on those buffaloes. On day 2 following parturition blood specimens were collected from jugular vein, and all efforts were done to decrease the distress. The samples were obtained from 287 calved buffaloes throughout two years where only 40 samples were selected for the current study depending on time of placental expulsion. Other 20 samples were collected from non-calved buffaloes (HEF). So, the samples were divided into three groups, group I HEF group $(n=20)$, group II buffaloes expelled their placenta within 12 hours after parturition (NRP group) ( $n=20)$ and group III buffaloes didn't expel their placenta within 12 hours and were diagnosed with RP (RP group) ( $\mathrm{n}=20)$.

\section{Biochemical Study}

Fasting serum BG was determined on the base of glucose-oxidase peroxidase method. Serum TC, TG and HDL-c was determined using commercial kits. However low density lipoprotein cholesterol (LDL-c) and very low density lipoprotein cholesterol (VLDL-c) levels were calculated according to previous formula of (Fawwad et al., 
Table 1: Primer sequence and PCR product length

\begin{tabular}{|c|c|c|c|c|}
\hline Gene & \multicolumn{2}{|c|}{ Primer sequence } & Gene bank accession No. & Product length \\
\hline \multirow[t]{2}{*}{ G3PDH } & $\mathrm{F}$ & 5'-GCCAGTAGAAGCAGGGATGA-3' & \multirow[t]{2}{*}{ NM_001190390.1 } & \multirow[t]{2}{*}{$423 \mathrm{bp}$} \\
\hline & $\mathrm{R}$ & 5'-AAGGCCATCACCATCTTCCA-3' & & \\
\hline \multirow[t]{2}{*}{ IL-1 $\beta$} & $\mathrm{F}$ & 5'-TGGCACTCTAACCCGGAAAT-3' & \multirow[t]{2}{*}{ NM_174093.1 } & \multirow[t]{2}{*}{$449 \mathrm{bp}$} \\
\hline & $\mathrm{R}$ & 5'-AAAGCCATACCCAGGGAGTC-3' & & \\
\hline \multirow[t]{2}{*}{ IL-6 } & $\mathrm{F}$ & 5'-GTCAGTGTTTGTGGCTGGAG-3' & \multirow[t]{2}{*}{ NM_173923.2 } & \multirow[t]{2}{*}{$444 \mathrm{bp}$} \\
\hline & $\mathrm{R}$ & 5'-ACTTCTGCTTTCCCTACCCC-3' & & \\
\hline
\end{tabular}

2016; Srilatha et al., 2017) respectively. Also, kinetic method was performed to measure ALT and AST activity in serum samples according to instruction of kits. However, colorimetric procedure was used to assay both urea and creatinine concentrations in all examined samples. TP was analyzed according to previous method recorded by Witt and Trendelenburg (1982). Serum albumin was assayed according to manufacture of kit's instructions and globulin concentration and albumin/globulin $(\mathrm{A} / \mathrm{G})$ ratio were calculated (Samanta et al., 2016).

Biochemical estimation of some macro and micro-minerals was also performed in our work. Analysis of $\mathrm{Zn}^{2+}$ was done dependent on Johnsen and Eliasson (1987) method. Also, $\mathrm{Ca}^{2+}$ level in serum samples was determined by colorimetric quantitative method according to kits instruction. In addition, the colorimetric determination of $\mathrm{TF}, \mathrm{Mg}^{2+}$ and $\mathrm{Cu}^{2+}$ was carried out according to Williams et al. (1977), Farrell (1984) and Young (2001) respectively.

Moreover, serum lipid peroxidation (LPO) was estimated by the reaction of malonyldialdehyde (MDA) as a major secondary product of LPO with thiobarbituric acid to produce thiobarbituric acid reactive substances (Eukaszewicz-Hussain et al., 2007). Nitric oxide (NO) level was also measured using Chavda and Udhnawala (2019) technique with slight modification.

Serum TAC was performed by colorimetric enzymatic reaction method (Koracevic et al., 2001). GSH content was determined as described previously (Giustarini et al., 2017). Specific activity of serum SOD was also assessed depending on the ability of SOD to prevent auto-oxidation of pyrogallol (Marklund and Marklund, 1974).

Hormonal analysis of serum $\mathrm{P}_{4}$ and $\mathrm{E}_{2}$ were also done individually via their specific ELISA kits according to guidelines of their instructions.

\section{Molecular Study}

Molecular study of serum IL-1 $\beta$ and IL- 6 was carried out and G3PDH was used as an internal control gene which is termed also housekeeping gene where it was used as an internal standard and it isn't affected by any experimental disorders. First total RNA was isolated from serum samples by spin column method using commercial kits according to manufacture of instructions. After that, isolated RNA was reverse transcribed to cDNA according to kits guidelines where $1 \mu \mathrm{g}$ of template RNA and RNase free $\mathrm{H}_{2} \mathrm{O}$ were added into the Maxime RT pre mix to a total volume of $20 \mu \mathrm{l}$. After that the mixtures were let stand at RT tubes for $2 \mathrm{~min}$., then the mixtures were dissolved well by pipetting and cDNA synthesis reaction was performed by using polymerase chain reaction (PCR) machine according to the following conditions: step of DNA synthesis at $45^{\circ} \mathrm{C}$ for $60 \mathrm{~min}$. and RTase inactivation step at $95^{\circ} \mathrm{C}$ for $5 \mathrm{~min}$. For gene expression normal PCR was performed, the nucleotide sequence of gene-specific primers were constructed using NCBI data base (Table 1). PCR program was adjusted for each primer pair using PCR thermal cycle. The reaction mixture was consisted from $12.5 \mu 1$ of $2 \mathrm{X}$ Taq master mix, $1 \mu \mathrm{l}$ of diluted forward primer, $1 \mu \mathrm{l}$ of diluted reverse primer, $5.5 \mu \mathrm{l}$ of RNase free $\mathrm{H}_{2} \mathrm{O}$ and $5 \mu \mathrm{l}$ of cDNA which was used as template to amplify G3PDH, IL-1 $\beta$ and IL-6. The mixtures were mixed well using vortex and entered in PCR machine where PCR thermal cycle was carried and it was started by initial denaturation at $94^{\circ} \mathrm{C}$ for $2 \mathrm{~min}$. followed by 35 cycles of PCR, each consisted of $2 \mathrm{sec}$. denaturation at $94^{\circ} \mathrm{C}, 30 \mathrm{sec}$. annealing at $64^{\circ} \mathrm{C}$ for G3PDH, $64.5^{\circ} \mathrm{C}$ for IL- $1 \beta$ and $64.1^{\circ} \mathrm{C}$ for IL-6 and final cycle was $30 \mathrm{sec}$. extension at $72^{\circ} \mathrm{C}$.

Then gel electrophoresis was performed for PCR product and DNA marker used as a positive indicator using 1.5\% agrose gel in Horizontal Electrophoresis unit and illuminated with $30 \mathrm{~nm}$ U.V Radiator and photographic record was made. Optical density of bands was calculated by GelQuantNET software program. Then relative gene expression was calculated according to the following equation:

Relative gene expression $=$

Intensity of specific gene band Intensity of corresponding band G3PDH expression

Additionally sodium dodecyl sulfate poly acrylamide gel electrophoresis (SDS-PAGE) of serum samples was done to identify if there was any alteration in protein profile in 
all studied groups. It was performed after determination of TP concentration according to Green and Sambrook (2012) where $27 \mu \mathrm{g}$ of protein sample was subjected to electrophoresis in presence of 30\% acrylamide, detergent SDS and reducing agent $ß$-mercaptoethanol using EcoMini Vertical Electrophoresis unit. Protein bands were visualized then illuminated by gel documentation system and molecular weight (Mwt) of visualized protein bands was determined by comparing them with Mwt of protein ladder. The percentage of protein amount in each sample was calculated using Documentation Program Gel Pro Analyzer.

\section{STATistical AnAlysis}

Results were computed and statistically analyzed by means of the program SPSS (Version 16, one way ANOVA-test). Results are presented as mean $\pm \mathrm{SE}$ and the $\mathrm{p}$-value $<0.05$ was reflected statistical significant.

\section{RESULTS}

The incidence of RP was recorded as $19.04 \%$ in studied group of calved buffaloes used for the current work. Gynecological examination of RP group showed presence of persistent corpus luteum (CL) on ovaries and some buffaloes were suffered from endometritis with bloody purulent offensive vaginal discharge after 2 days postpartum. Also rectal palpation of $\mathrm{HEF}$ group revealed absence of $\mathrm{CL}$ which indicates the studied HEF was cyclic in follicular phase.

Gene expression of IL-1 $\beta$ and IL-6 against glycerol-3phosphate dehydrogenase (G3PDH) was revealed in Table 2 and Figure 1. where they decreased by $80.9 \%$ and $9.6 \%$ respectively in $\mathrm{RP}$ comparing to NRP. Comparing by $\mathrm{HEF}$, NRP showed highly significant elevation of both IL-1 $\beta$ and IL-6 $(\mathrm{P}<0.001)$ while $\mathrm{P}$-value of RP in case of IL-1 $\beta$ was $<0.001$ and $<0.01$ in case of IL-6. Also, serum TP level was decreased by $13.0 \%$ and albumin was also declined by $50.2 \%$ in RP comparing to NRP. However, serum globulin was increased by $30.1 \%$ in RP. Also, reduction of calculated $\mathrm{A} / \mathrm{G}$ ratio was observed $(\mathrm{P}<0.05)$ in case of $\mathrm{RP}$ (Figure 2$)$. Significant decline of TP in NRP and RP $(8.32 \pm 0.26$ and $7.24 \pm 0.16$, respectively) was noticed compared to HEF $(10.32 \pm 0.52)$. In group of RP only there was significant decline of albumin compared to $\operatorname{HEF}(\mathrm{P}<0.001)$. However globulin was increased in RP and NRP and $\mathrm{A} / \mathrm{G}$ ratio was significant declined compared to $\mathrm{HEF}$.

SDS-PAGE was used to differentiate between HEF, NRP and RP groups according to their protein extract content and the results are recorded in Figure 3. where protein ladder was separated into several bands (Mwt from 6.5 to 270 KDa). HEF group was separated into nearly 18 bands with
Table 2: Gene expression of serum IL-1 $\beta$ and IL-6 against G3PDH in Egyptian buffaloes before and after calving in presence and absence of RP

$\begin{array}{lll}\text { Groups } & \text { IL-1//G3PDH } & \text { IL-6/G3PDH } \\ \text { HEF } & 0.05 \pm 0.01 & 0.31 \pm 0.03 \\ \text { NRP } & 0.47 \pm 0.02^{\mathrm{a}} & 0.73 \pm 0.01^{\mathrm{a}} \\ \text { RP } & 0.09 \pm 0.01^{\mathrm{b}} & 0.66 \pm 0.01^{\mathrm{a}}\end{array}$

Values represent mean \pm SE. SPSS version 16 (one way ANOVA test). Significance: ${ }^{a} \mathrm{P}<0.001,{ }^{b} \mathrm{P}<0.01,{ }^{\mathrm{c}} \mathrm{P}<0.05$ comparing to HEF.

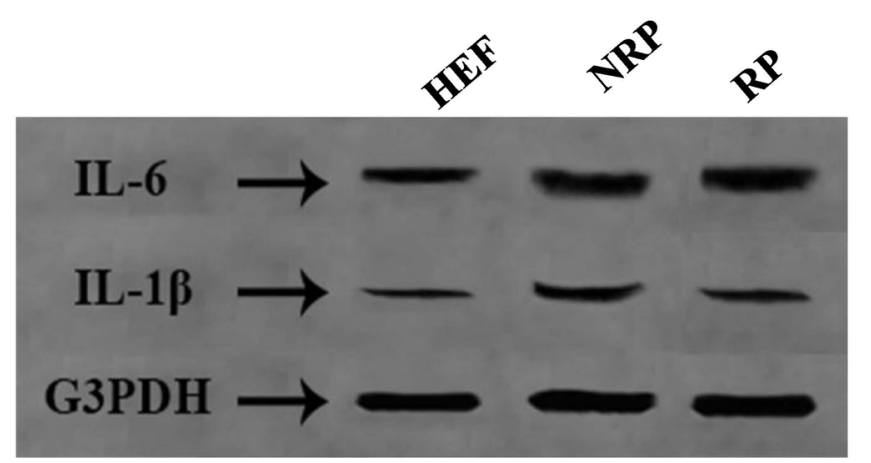

Figure 1: Agrose gel electrophoresis of IL-1 $\beta$ (449 bp) and IL-6 (444 bp) against G3PDH (423 bp) as a house keeping gene.

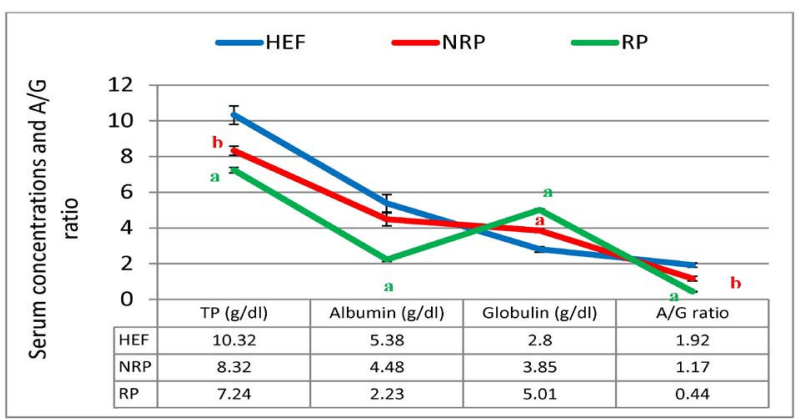

Figure 2: TP, albumin, globulin and A/G ratio of serum Egyptian buffaloes before and after calving in presence and absence of RP. Values are expressed as mean $\pm \mathrm{SE}(\mathrm{n}=20)$. Significance: ${ }^{\mathrm{a}} \mathrm{P}<0.001,{ }^{\mathrm{b}} \mathrm{P}<0.01,{ }^{\mathrm{c}} \mathrm{P}<0.05$ comparing to HEF.

varied Mwt from (7 to $130 \mathrm{KDa}$ ). NRP group was separated into nearly 16 bands with different Mwt from (7 to 165 KDa). RP group was separated into nearly 14 bands with different Mwt from (7 to $173 \mathrm{KDa}$ ). Several differences in serum protein composition were obvious between the three groups. From those variations increase the levels of a 58and $57-\mathrm{KDa}$ in the serum of $\mathrm{HEF}$ and RP as compared to NRP and those proteins demonstrated to be collagen. Another difference was decrease the levels of a 25- and 17$\mathrm{KDa}$ in case of HEF and RP than NRP group and those proteins were revealed to be IL- 6 and IL- $1 \beta$ respectively, however the decline was more obvious in HEF. Further presence of a $60-\mathrm{KD}$ a protein in $\mathrm{RP}$ that was absent or in 
low amounts in NRP serum and this protein is shown to be $\mathrm{P}_{4}$. However $\mathrm{E}_{2}$ protein was appeared in a huge quantity at a $70-\mathrm{KDa}$ in $\mathrm{HEF}$ and NRP group than RP. Also, it was reported decline of $72-\mathrm{KD}$ a protein in $\mathrm{HEF}$ and RP than NRP and this protein recognized to be prostaglandin (PG).

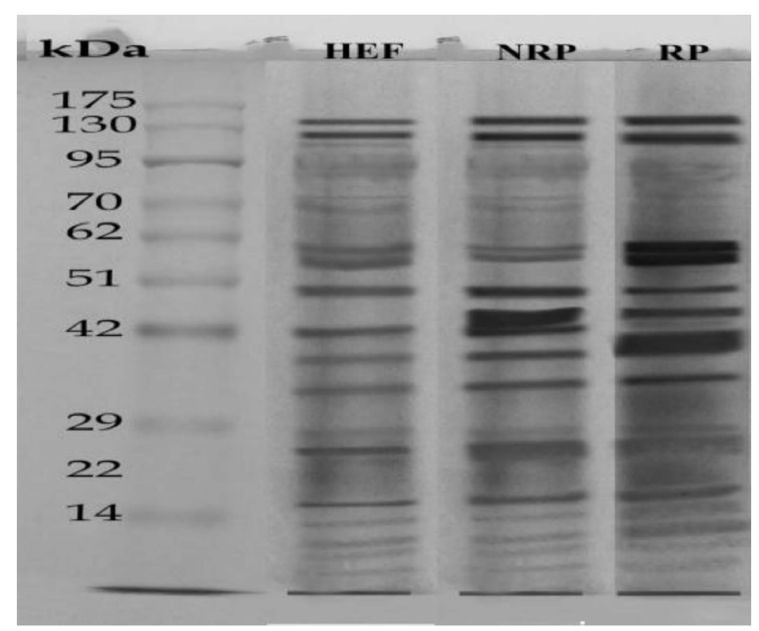

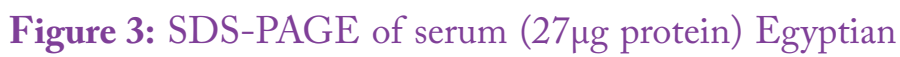
buffaloes before and after calving in presence and absence of RP. The separation was done on discontinuous system using 4\% stacking gel and $12 \%$ separating gel then, fixing, staining and de-staining of obtained gel. Lan (1) represented HEF group, Lan (2) is NRP group and Lan (3) is $\mathrm{RP}$ group.

Additionally buffaloes have RP exhibited an increasing affinity in BG level $(\mathrm{P}<0.001)$ within 2 days after parturition compared to NRP and HEF. At lipid profile level it was noticed in RP group elevation of serum TC and TG by $27.7 \%$ and $33.7 \%$ respectively, while HDL-c was reduced by $42.9 \%$ comparing to NRP. Further, serum LDL-c in relation to RP revealed significant increase $(\mathrm{P}<0.01)$ however; VLDL-c hasn't any significant variation comparing to NRP. By comparing NRP by HEF at lipid profiles it was reported significant elevation of TG $(\mathrm{P}<0.01)$ and fall of HDL-c $(\mathrm{P}<0.05)$. Additionally RP showed significant increase of TC, TG and LDL-c $(\mathrm{P}<0.001)$ decrease of HDL-c and VLDL-c $(\mathrm{P}<0.001$ and $<0.001$, respectively) when compared to HEF (Figure 4).

In Figure 5 and 6 serum MDA, NO, SOD, GSH and TAC were shown. Serum MDA and NO were found to be significantly elevated ( 3.8 and 1.3 -folds, respectively) in buffaloes with RP than NRP. While SOD specific activity, GSH concentration and TAC were decreased $59.5 \%, 57.1 \%$ and $75.4 \%$ respectively. Also, NRP showed significant increase of $\mathrm{NO}(0.39 \pm 0.04)$ compared to HEF $(0.19 \pm 0.02)$ and reduction of GSH and TAC $(\mathrm{P}<0.05$ and $<0.001$, respectively). Moreover, RP showed significant rise of MDA and NO and dimension of SOD, GSH and TAC $(\mathrm{P}<0.001)$ in comparison to HEF.

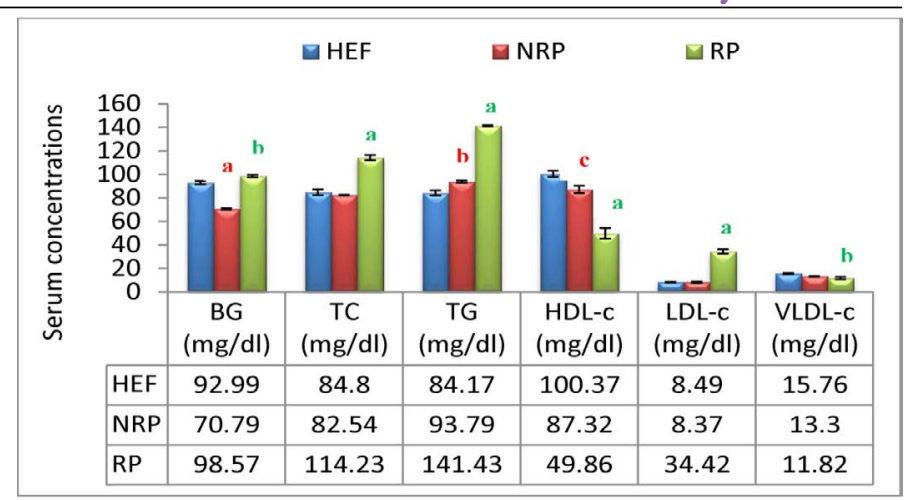

Figure 4: BG, TC. TG, HDL-c, LDL-c and VLDL-c of serum Egyptian buffaloes before and after calving in presence and absence of RP. Values are expressed as mean \pm SE $(n=20)$. Significance: ${ }^{a} \mathrm{P}<0.001,{ }^{b} \mathrm{P}<0.01,{ }^{\mathrm{C}} \mathrm{P}<0.05$ comparing to $\mathrm{HEF}$.

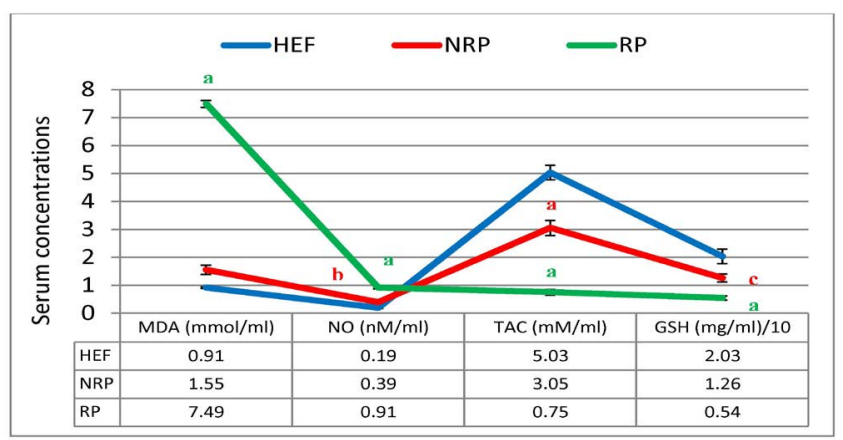

Figure 5: MDA, NO, TAC and GSH of serum Egyptian buffaloes before and after calving in presence and absence of RP. Values are expressed as mean $\pm \mathrm{SE}(\mathrm{n}=20)$. Significance: ${ }^{\mathrm{a}} \mathrm{P}<0.001,{ }^{\mathrm{b}} \mathrm{P}<0.01,{ }^{\mathrm{c}} \mathrm{P}<0.05$ comparing to HEF.

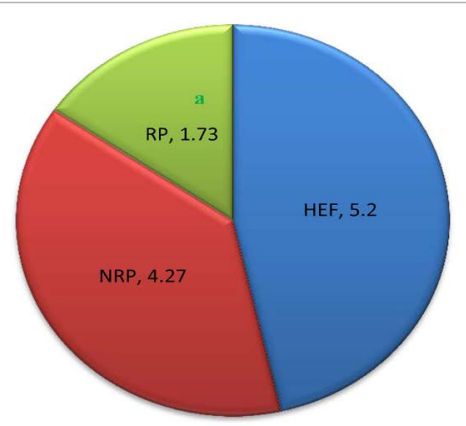

Figure 6: SOD specific activity of serum Egyptian buffaloes before and after calving in presence and absence of RP. Values are expressed as mean $\pm \mathrm{SE}(\mathrm{n}=20)$. Significance: ${ }^{\mathrm{P}} \mathrm{P}$ $<0.001,{ }^{\mathrm{b}} \mathrm{P}<0.01,{ }^{\mathrm{c}} \mathrm{P}<0.05$ comparing to HEF.

At hormonal level it was observed that serum $\mathrm{E}_{2}$ was diminished by $61.1 \%$ in RP however $\mathrm{P}_{4}$ was elevated by $35.6 \%$ in RP compared to NRP group. Further, $\mathrm{E}_{2}$ level was significant decline in NRP and RP $(94.30 \pm 3.21$ and $36.73 \pm 5.50$, respectively) compared to HEF (115.86 \pm 
2.18). However $\mathrm{P}_{4}$ level was increased in both $\mathrm{NRP}$ and $\mathrm{RP}(6.73 \pm 0.38$ and $9.13 \pm 0.15$, respectively) comparing with HEF (4.69 \pm 0.21$)$ (Table 3).

Table 3: Serum concentrations of $\mathrm{E}_{2}(\mathrm{pg} / \mathrm{ml})$ and $\mathrm{P}_{4}$ (ng/ $\mathrm{ml}$ ) of Egyptian buffaloes before and after calving in presence and absence of RP

$\begin{array}{lll}\text { Groups } & \mathbf{E}_{2}(\mathbf{p g} / \mathbf{m l}) & \mathbf{P}_{4}(\mathbf{n g} / \mathbf{m l}) \\ \text { HEF } & 115.86 \pm 2.18 & 4.69 \pm 0.21 \\ \text { NRP } & 94.30 \pm 3.21^{\mathrm{b}} & 6.73 \pm 0.38^{\mathrm{a}} \\ \text { RP } & 36.73 \pm 5.50^{\mathrm{a}} & 9.13 \pm 0.15^{\mathrm{a}}\end{array}$

Values represent mean \pm SE. SPSS version 16 (one way ANOVA test). Significance: ${ }^{\mathrm{a}} \mathrm{P}<0.001,{ }^{\mathrm{b}} \mathrm{P}<0.01,{ }^{\mathrm{c}} \mathrm{P}<0.05$ comparing to HEF.

Table 4: Serum activities of ALT and AST (I/U) and levels of urea and creatinine $(\mathrm{mg} / \mathrm{dl})$ in Egyptian buffaloes before and after calving in presence and absence of RP

$\begin{array}{lllll}\text { Groups } & \begin{array}{l}\text { ALT } \\ (\mathbf{I} / \mathbf{U})\end{array} & \begin{array}{l}\text { AST } \\ (\mathbf{I} / \mathbf{U})\end{array} & \begin{array}{l}\text { Urea } \\ (\mathbf{m g} / \mathbf{d l} \mathbf{l})\end{array} & \begin{array}{l}\text { Creatinine } \\ (\mathbf{m g} / \mathbf{d} \mathbf{l})\end{array} \\ \mathrm{HEF} & 27.57 \pm & 25.96 \pm & 20.69 \pm & 0.93 \pm 0.04 \\ & 0.37 & 0.55 & 0.95 & \\ \mathrm{NRP} & 27.77 \pm & 26.13 \pm & 24.33 \pm & 1.07 \pm 0.09 \\ & 0.94 & 0.86 & 0.67 & \\ \mathrm{RP} & 46.53 \pm & 38.17 \pm & 37.0 \pm & 0.9 \pm 0.02 \\ & 1.82^{\mathrm{a}} & 2.55^{\mathrm{b}} & 1.73^{\mathrm{a}} & \end{array}$

Values represent mean \pm SE. SPSS version 16 (one way ANOVA test). Significance: ${ }^{\mathrm{a}} \mathrm{P}<0.001,{ }^{\mathrm{b}} \mathrm{P}<0.01,{ }^{\mathrm{c}} \mathrm{P}<0.05$ comparing to HEF.

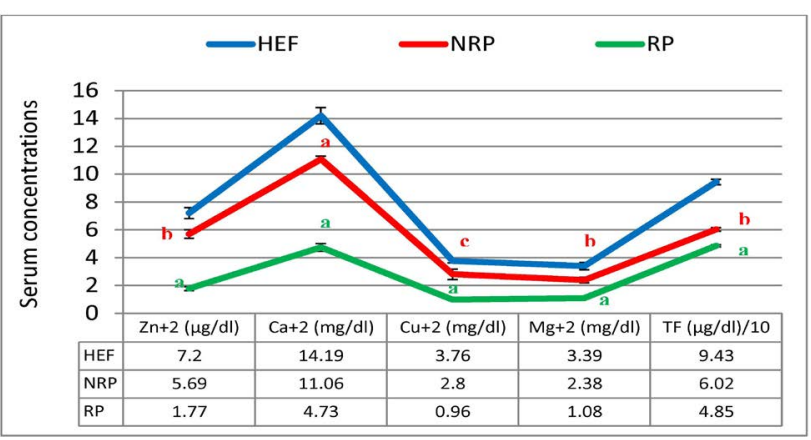

Figure 7: $\mathrm{Zn}^{+2}, \mathrm{Ca}^{+2}, \mathrm{CU}^{+2}, \mathrm{Mg}^{+2}$ and $\mathrm{TF}$ of serum Egyptian buffaloes before and after calving in presence and absence of RP. Values are expressed as mean $\pm \mathrm{SE}(\mathrm{n}=20)$. Significance: ${ }^{\mathrm{a}} \mathrm{P}<0.001,{ }^{\mathrm{b}} \mathrm{P}<0.01,{ }^{\mathrm{c}} \mathrm{P}<0.05$ comparing to HEF.

Moreover the mean of studied $\mathrm{Ca}^{2+}$ and $\mathrm{Mg}^{2+}$ values showed reduction trend by $57.23 \%$ and $54.62 \%$ respectively in case of RP compared to NRP. Also, essential trace minerals in $\mathrm{RP}$ revealed decline in $\mathrm{Zn}^{2+}, \mathrm{Cu}^{2+}$ and $\mathrm{TF}$ by $68.9 \%$, $65.7 \%$ and $19.4 \%$ respectively. Additionally all studied minerals exhibited significant reduction in both NRP and RP groups compared to HEF group (Figure 7). Also, serum ALT and AST activities and urea concentration was elevated by $67.6 \%, 46.1 \%$ and $52.1 \%$ respectively in case of $\mathrm{RP}$ compared to NRP and also significant elevation was reported when compared to HEF $(\mathrm{P}<0.001$ and $<0.01)$. Conversely, there was no significant difference in serum creatinine level between RP and NRP and HEF groups $(\mathrm{P}>0.05)$ (Table 4).

\section{DISCUSSION}

Reproductive problems in buffaloes related to parturition take more attention nowadays due to their side effects on the production and fertility with subsequent economic loss. The normal sequence of parturition is influenced by number of endocrine and paracrine factors. It begins with gradual decrease of placental $\mathrm{P}_{4}$ concentration and increased production of $\mathrm{E}_{2}$ hormone where $\mathrm{E}_{2}$ has a vital role in the growth of placentomes and PG release (Attupuram et al., 2016). The role of albumin during normal parturition occupies huge significance as it is a source of endogenous amino acids which are required postpartum (Bhat et al., 2018).

Parturition is provoked by inflammation that leads to uterine contractions with subsequent ejection of the newborn and the fetal membranes. Several pro-inflammatory mediators, containing cytokines, are released into the feto-maternal interface for the preparation to parturition and during it. This starts, in humans and cows, from recognition of the fetal antigens by maternal immune system in such a way similar to a graft rejection like reaction (Jaworska and Janowski, 2019). Pro-inflammatory cytokines, IL-1 $\beta$ and IL-6, participate in the events of parturition by activation of immune cells and they are linked to PG signaling pathway (Keelan et al., 2003). IL-1 $\beta$, IL-6 and, tumor necrosis factor alpha (TNF- $\alpha)$ are biomarkers which their expression significantly elevates in placental tissues throughout parturition in human and cows. Also, both IL$1 \beta$ and TNF- $\alpha$ enhance PG production and they are able to activate the nuclear factor kappa-B signaling pathway, which further stimulates myometrial contractions. In addition, the inflammatory process must be properly tuned to ensure that it will not exert any harmful effect along the course of parturition and, subsequently, the mother and the fetus. An altered inflammatory response in cows is presumably one of the causes that lead to RP (Jaworska and Janowski, 2019). Our data revealed significant decrease in IL-1 $\beta$ gene expression, this result is in the same aspect with Islam et al. (2013) who recorded significant reduction in the serum level of IL-1 $\beta$ fifteen days before parturition and continued to the fifteenth day post-delivery which indicates disturbed immune response with subsequent RP. Also, our results match with (Shimizu et al., 2018) who found that IL-1 $\beta$ gene expression was significantly lower in peripheral blood mononuclear cells at 4 weeks postpar- 
tum in RP dairy cows than control ones. IL-6 has a role in the normal physiological processes of parturition as it is expressed in the female reproductive tract and gestational tissues and also it regulates the growth of placenta and helps in embryo implantation (Gomez-Lopez et al., 2016). It was reported that IL-6 affects low $P_{4}$ level and activates genes of uterus which are responsible for normal delivery (Robertson et al., 2010). Moreover, IL-6 stimulates the adaptive immune response which may take place throughout parturition (Jaworska and Janowski, 2019). In this work, IL-6 gene expression was significantly decreased in RP in comparison with NRP, this result is in the same line with (Ishikawa et al., 2004) who recorded low level of the peripheral blood IL-6 before parturition which associated with defect in placental function that contribute to RP. They suggested that the cause of RP was due to abnormality of the shift in the immune response during delivery.

Moreover, $\mathrm{RP}$ is associated with imbalances in $\mathrm{E}_{2}$ and $\mathrm{P}_{4}$ levels. High $\mathrm{P}_{4}$ and low $\mathrm{E}_{2}$ levels were occurred due to failure of the placenta to produce sufficient amounts of cytochrome P450 aromatase enzyme which has a role in catalyzing the rate limiting step in $\mathrm{E}_{2}$ biosynthesis (Attupuram et al., 2016). Further, lower levels of IL-6 in RP syndrome affected buffaloes may lead to reduction in the expression of Cyp19 gene which encodes cytochrome $\mathrm{P} 450$ aromatase enzyme so; inadequate $\mathrm{E}_{2}$ production will be happened leading to the formation of undeveloped placentomes which aren't expelled out naturally causing RP (Ghai et al., 2012).

Also, prostaglandins have a key role in normal delivery through uterine contraction activation and they help in the release of the placenta (Grillo-Ardila et al., 2018). Production of $\mathrm{PG}$ is usually connected to $\mathrm{E}_{2}$ so reduction of $P G$ level in RP can be a consequence of $E_{2}$ deficiency (Yasuhara et al., 2019). Further prostaglandin-F-2-alpha $\left(\mathrm{PG}-\mathrm{F}_{2} \alpha\right)$ is responsible for CL lysis hence it is suspected that low level of PG- $\mathrm{F}_{2} \alpha$ is one of contributing factors for enhancement RP syndrome (Parmar et al., 2016). Our results at protein level exhibited low PG in RP which parallel to those Wischral et al. (2001) who stated that PG$\mathrm{F}_{2} \alpha$ metabolites decline in cows failed to release their fetal membranes.

As a consequence of tissue destruction and inflammation during the period of RP in attempts to eject the placenta, the production of protein in liver is partly altered towards increased synthesis of positive acute phase proteins and reduction of albumin which is a negative acute phase protein and elevation of globulin, hence diminishing of $\mathrm{A} / \mathrm{G}$ will be occurred (Saleh et al., 2008). In addition, the current results revealed a raise in the level of the serum collagen in RP group which attributed to its failing to perform the normal function as it wasn't consumed in placenta remov- ing process (Beagley et al., 2010). Normally, during parturition caruncle cotyledon collagen had been broken under the effect of , matrix metalloproteinase type-2 (MMP-2) to facilitate separation of the placenta (Hiebel et al., 2019). Our data came in accordance with Dilly et al. (2011) who noticed elevation of MMP-2 in animals has RP than others so direct relationship between MMP-2 and collagen level.

Moreover, it was recognized that buffaloes which released their placenta within $12 \mathrm{~h}$ postpartum showed decline in glucose level due to utilization of glucose required for lactose synthesis (Cui et al., 2019). However, the current data observed hyperglycemia and hyperlipidemia in buffaloes with RP which is expected due to insulin resistance that linked with RP while the concentration of insulin wasn't measured in our study. Another hypothesis of hyperglycemia may be attributed to elevation of cortisol as a consequence of stress factor produced from RP (Cheung et al., 2019). Hypocalcemia which observed in RP may be another factor of hyperglycemia because the decline of $\mathrm{Ca}^{2+}$ level prevents insulin production (Chen et al., 2016). Also, severe hyperlipidemia in RP leads to accumulation of lipids inside the hepatocytes and subsequently increase in the activity of the liver enzymes and liver injury (Joksimovic-Todorovic and Davidovic, 2013).

In general parturition is considered as one of stress factors on animals due to changes in $\mathrm{O}_{2}$ use and pressure and it is associated with reactive oxygen species (ROS) production. $\mathrm{RP}$ constitutes more stress on the animals which become more susceptible to immune suppression (Kankofer et al., 2010). The imbalance in ROS production is one of the predisposing factors which cause improper release of placenta. Hence study of antioxidant defense system such as TAC, SOD and GSH was very crucial matter during current work. The present work showed reduction of SOD activity, TAC and GSH level in RP comparing to NRP which attributed to multi factors including the reduced production of $\mathrm{E}_{2}$ and $\mathrm{PG}-\mathrm{F}_{2} \alpha$ and accumulation of arachidonic and linoleic acids in the placental tissue (Abdisa, 2018). Concerning to SOD decline, it is expected due to shortage of some micro-minerals concentration such as $\mathrm{Cu}^{2+}$ and $\mathrm{Zn}^{2+}$. From biochemical theme $\mathrm{Cu}^{2+}$ and $\mathrm{Zn}^{2+}$ are involved in the function of SOD enzyme, so reduction of those minerals indirectly proportional with SOD activity. Further, lower serum TAC in RP is attributed to disturbances in anti-oxidative/oxidative balance and is confirmed by reduction of SOD specific activity. Current findings is confirmed by previous data of Kankofer et al. (2005) who noticed an elevation of TAC in placental tissue of cows affected with $\mathrm{RP}$ as compared to those without RP which indicates a transfer of TAC from blood to placental tissue.

Moreover, our results exhibited that RP is associated with elevation of MDA and NO concentration which come in 
line with preceding studies (Jovanovic et al., 2013; Islam and Kumar, 2015). MDA is an indicator of lipids peroxidation which associated with presence of poisonous metabolites and destruction of free fatty acids and phospholipids (Erisir et al., 2006). We assumed that high level of MDA was predicted as a result of metabolic and endocrine changes related to RP (Yildiz et al., 2011). While, elevation of $\mathrm{NO}$ may be related to the imbalance of $\mathrm{P}_{4}$ concentration leading to $\mathrm{NO}$ metabolites production which are the main source of elevated NO level where both NO and $\mathrm{P}_{4}$ play a significant role in preserving placental perfusion during the gestational period by inducing smooth muscle relaxation (Chwalisz and Garfield, 1998).

As a consequence of alteration of anti-oxidative defense system during RP, various degrees of renal and hepatic tissue injuries will be occur which may be attributed to the impairment of the mitochondrial function during the oxidative stress (Cahova et al., 2015).

In this study the effect of RP on some minerals was displayed where the imbalance was clearly observed and directly effect on several metabolic pathways inside buffaloes' body. Gynecological inspection showed reduction of uterine muscle contractility in case of RP which attributed to shortage of $\mathrm{Ca}^{2+}$ (Talukdar et al., 2016). From biochemical background hypocalcemia is usually associated with hypomagnesemia which cause hyperexcitability of uterine muscle. Data in the current work are like to previous study in cows (Qu et al., 2014).

Also, it was reported that buffaloes with RP significantly deficient in $\mathrm{Zn}^{2+}$ which has important role in preserving the uterus following parturition as it helps in healing process and immune system during convalescent stage (Bicalho et al., 2014). In normal physiological conditions most of maternal iron is transferred to the fetus during last trimester of gestation so the reduction of TF in serum of dam is considered normal (Cao and O'brien, 2013). In the light of our findings TF in case of RP was lower than NRP which attributed to $\mathrm{Cu}^{2+}$ reductions as it required for biosynthesis of hemoglobin.

All our obtained results were confirmed by rectal and vaginal examination which revealed increased the size of uterus with presence of bloody and purulent vaginal discharge with offensive odor in buffaloes with RP and this was in harmony with previous work (Khan et al., 2015).

\section{CONCLUSION}

From this study, it was concluded that the lower immunity (reduction in IL-6 and IL-1 $\beta$ ) during parturition in Egyptian buffaloes may be the predisposing cause of retained placenta. Buffaloes with retained placenta were predicta- ble to have low level of antioxidant system and high level of pro-oxidants compared to buffaloes without retained placenta. Based on our data in protein profile and minerals concentration in case of heifers, buffaloes with and without retained placenta, we conclude that improvement of nutrition during the pregnancy may serve as a tool for decreasing retained placenta occurrence. Furthermore, to understand the mechanism of low immunity and oxidative stress in relation to retained placenta we need to broaden the spectrum of study so we recommend further studies in such aspect.

\section{ACKNOWLEDGMENTS}

The authors thank Biological Screening and Preclinical Trial Lab, Biochemistry Department, Faculty of Science, Alexandria University, Alexandria, Egypt for financial support.

\section{CONFLICT OF INTEREST}

The authors haven't conflict of interest to declare.

\section{AUTHORS CONTRIBUTION}

Mervat Hassan prepared the idea of the manuscript, blood sampling and gynecological examination. Nani Nasreldin analyzed some biochemical parameters and wrote the discussion part of the pro-inflammatory cytokine (IL-1 $\beta$ and IL-6) in the original manuscript draft. Marwa El-Zeftawy analyzed some biochemical parameters and all molecular parameters, she did statistical analysis of the results and wrote the original manuscript draft. Also she was the corresponding author who responded the journal requests during reviewing and editing. All authors are contributed in revising the final draft of the manuscript.

\section{REFERENCES}

-Abdisa T (2018). Mechanism of retained placenta and its treatment by plant medicine in ruminant animals in Oromia, Ethiopia.J. Vet. Med. Anim. Health.10(6): 135-147.https:// doi.org/10.5897/JVMAH2018.0672.

-Attupuram NM, Kumaresan A, Narayanan K, Kumar H (2016). Cellular and molecular mechanisms involved in placental separation in the bovine: A review. Mol. Reprod. Dev. 83(4): 287-297. https://doi.org/10.1002/mrd.22635.

- Beagley JC, Whitman KJ, Baptiste K.E, Scherzer J (2010). Physiology and treatment of retained fetal membranes in cattle. J. Vet. Intern. Med. 24(2): 261-268. https://doi. org/10.1111/j.1939-1676.2010.0473.x.

- Bhat IA, Bashir S, Rather W, Iqbal Z, Kawa AQ, Hussain SA, Beigh SA, Nabi S, Dar AA (2018). Acute Phase Proteins and their Clinical Significance in Veterinary Medicine: An Overview. Pharma Innov. 7(1): 104-108. 
- Bicalho MLS, Lima FS, Ganda EK, Foditsch C., Meira Jr EBS, Machado VS, Teixeira AGV, Oikonomou G, Gilbert RO, Bicalho RC (2014). Effect of trace mineral supplementation on selected minerals, energy metabolites, oxidative stress, and immune parameters and its association with uterine diseases in dairy cattle. J. Dairy Sci. 97(7): 4281-4295. https://doi. org/10.3168/jds.2013-7832.

-Burton GJ, Fowden AL (2015). The placenta: a multifaceted, transient organ. Philos. Trans. R. Soc. Lond. B. Biol. Sci. 370(1663): 20140066. https://doi.org/10.1098/ rstb.2014.0066.

- Cahova M, Palenickova E, Dankova H, Sticova E, Burian M, Drahota Z, Cervinkova Z, Kucera O, Gladkova C, Stopka P, Krizova J, Papackova Z, Oliyarnyk O, Kazdova L (2015). Metformin prevents ischemia reperfusion-induced oxidative stress in the fatty liver by attenuation of reactive oxygen species formation. Am. J. Physiol. Gastrointest. Liver Physiol. 309(2): G100-111. https://doi.org/10.1152/ ajpgi.00329.2014.

- Cao C, O'brien KO (2013). Pregnancy and iron homeostasis: an update. Nutr. Rev. 71(1): 35-51. https://doi.org/10.1111/ j.1753-4887.2012.00550.x.

- Chavda M, Udhnawala P (2019). Estimation of nitric oxide as an inflammatory marker in periodontitis. Int. J. Scient. Res. 8(6): 10-11.

- Chen C, Chmelova H, Cohrs CM, Chouinard, J. A.; Jahn, S. R.; Stertmann, J.; Uphues, I.; Speier, S. (2016). Alterations in $\beta$-cell calcium dynamics and efficacy outweigh islet mass adaptation in compensation of insulin resistance and prediabetes onset. Diabetes. 65(9): 2676-2685. https://doi. org/10.2337/db15-1718.

- Cheung NW, Wong KYC, Kovoor P, McLean M (2019). Stress hyperglycemia: A prospective study examining the relationship between glucose, cortisol and diabetes in myocardial infarction. J. Diab. Complicat. 33(4): 329-334. https://doi.org/10.1016/j.jdiacomp.2018.12.015.

- Chwalisz K, Garfield RE (1998). Nitric oxide as the final metabolic mediator of cervical ripening. Human Reprod. 13(2): 245-248.

- Cui L, Wang H, Ding Y, Li J, Li J (2019). Changes in the blood routine, biochemical indexes and the pro-inflammatory cytokine expressions of peripheral leukocytes in postpartum dairy cows with metritis. BMC. Vet. Res. 15(1): 157. https:// doi.org/10.1186/s12917-019-1912-y.

-Dilly M, Hambruch N, Shenavai S, Schuler G, Froehlich R, Haeger JD, Ozalp GR, Pfarrer C (2011). Expression of matrix metalloproteinase (MMP)-2, MMP-14 and tissue inhibitor of matrix metalloproteinase (TIMP)-2 during bovine placentation and at term with or without placental retention. Theriogenology. 75(6): 1104-1114. https://doi. org/10.1016/j.theriogenology.2010.11.019.

- Erisir M, Akar Y, Gurgoze SY, Yuksel M (2006). Changes in plasma malondialdehyde concentration and some erythrocyte antioxidant enzymes in cows with prolapsus uteri, caesarean section, and retained placenta. Revue. Med. Vet. 157(2): 80-83.

- Fareed SK; Memon KH, Kachiwal AB, Azhar S, Brula MI, U1Hasan M, Ali M, Khan TA (2017). Prevalence and economic losses of reproductive disorders and mastitis in buffaloes at Karachi, Pakistan. Indian J. Anim. Res. 51(6): 1130-1133. https://doi.org/10.18805/ijar.8602.

- Farrell E (1984). Magnesium. Kaplan A et al. Magnesium In: Clinical Chemistry ed. Kaplan LA et al. The C.V. Mosby
Co. St Louis. Toronto. Princeton. 1065-1069.

- Fawwad A, Sabir R, Riaz M, Moin H, Basit A (2016). Measured versus calculated LDL-cholesterol in subjects with type 2 diabetes. Pak. J. Med. Sci. 32(4): 955-960. https://doi. org/10.12669/pjms.324.9896

- Ganaie BA, Japheth KP, Ali M, Lone SA, Mir SH, Malik TA (2018). An Insight into the Pathophysiology, Preventive and Treatment Strategies of Retained Fetal Membranes in Bovines A Review. J. Anim. Health Prod. 6(2): 62-72. https://doi.org/10.17582/journal.jahp/2018/6.2.62.72.

- Ghai S, Monga R, Mohanty TK, Chauhan MS, Singh D (2012). Term placenta shows methylation independent down regulation of Cyp19 gene in animals with retained fetal membranes. Res. Vet. Sci. 92(1): 53-59. https://doi. org/10.1016/j.rvsc.2010.10.008.

- Giustarini D, Colombo G, Garavaglia ML, Astori E, Portinaro NM, Reggiani F, Badalamenti S, Aloisi AM, Santucci A, Rossi R, Milzani A, Dalle-Donne I (2017). Assessment of glutathione/glutathione disulphide ratio and S-glutathionylated proteins in human blood, solid tissues, and cultured cells. Free Radic. Biol. Med. 112: 360-375. https://doi.org/10.1016/j.freeradbiomed.2017.08.008.

-Gomez-Lopez N, Olson DM, Robertson SA (2016). Interleukin-6 controls uterine Th9 cells and CD8(+) T regulatory cells to accelerate parturition in mice. Immunol. Cell Biol.94(1): 79-89. https://doi.org/10.1038/icb.2015.63.

- Green MR, Sambrook J (2012). Molecular cloning. In: a laboratory manual: 3. Cold Spring Harbor, N. Y. Cold spring Harbor Laboratory Press.

- Grillo-Ardila CF, Amaya-Guio J, Ruiz-Parra AI, AmayaRestrepo JC (2018). Systematic review of prostaglandin analogues for retained placenta. Int. J. Gynaecol. Obstet. 143(1): 19-23. https://doi.org/10.1002/ijgo.12572.

- Hiebel K, Gentle L, Menino A, Kutzler M (2019). Acupuncture prevents the postpartum reduction in matrix metalloproteinase type-2 immunoexpression, tissue concentration and enzyme activity in bovine caruncles. Reprod. Domest. Anim. 54(7): 1010-1017. https://doi. org/10.1111/rda.13456.

- Ishikawa Y, Nakda K, Hagiwara K, Kirisawa R, Iwai H, Moriyoshi M, Sawamukai Y (2004). Changes in interleukin-6 concentration in peripheral blood of pre-and post-partum dairy cattle and its relationship to postpartum reproductive diseases. J. Vet. Med. Sci. 66(11): 1403-1408.

- Islam R, Kumar H (2015). Increased nitric oxide level around parturition in cows with or without postpartum uterine diseases. Indian J. Anim. Sci. 85(12): 35-38.

-Islam R, Kumar H, Nandi S, Mehrotra S (2013). Circulatory level of interleukin-1 in periparturient cows with or without postpartum reproductive diseases. Asian Pacific J. Reprod. 2(4): 316-320. https://doi.org/10.1016/s23050500(13)60170-0.

-Jaworska J, Janowski T (2019). Expression of proinflammatory cytokines IL-1beta, IL-6 and TNFalpha in the retained placenta of mares. Theriogenology. 126: 1-7. https://doi. org/10.1016/j.theriogenology.2018.11.029.

-Johnsen O, Eliasson R (1987). Evaluation of a commercially available kit for the colorimetric determination of zinc in human seminal plasma. Int. J. Androl. 10(2): 435-440. https://doi.org/10.1111/j.1365-2605.1987.tb00216.

-Joksimovic-Todorovic M, Davidovic V (2013). The effect of antioxidants on preventing the retained placenta in dairy cows. Biotechnol. Anim. Husband. 29(4): 581-589. https:// 
doi.org/10.2298/bah1304581j.

-Jovanovic IB, Velickovic M, Vukovic D, Milanovic S, Valcic O, Gvozdic D (2013). Effects of Different Amounts of Supplemental Selenium and Vitamin E on the Incidence of Retained Placenta, Selenium, Malondialdehyde, and Thyronines Status in Cows Treated with Prostaglandin F2alpha for the Induction of Parturition. J. Vet. Med. 2013: 867453. https://doi.org/10.1155/2013/867453.

- Kankofer M, Albera E, Feldman M, Gundling N, Hoedemaker M (2010). Comparison of antioxidative/oxidative profiles in blood plasma of cows with and without retained fetal placental membranes. Theriogenology. 74(8): 1385-1395. https://doi.org/10.1016/j.theriogenology.2010.06.009.

-Kankofer M, Lipko J, Zdunczyk S (2005). Total antioxidant capacity of bovine spontaneously released and retained placenta. Pathophysiology. 11(4): 215-219. https://doi. org/10.1016/j.pathophys.2005.01.001.

-Keelan JA, Blumenstein M, Helliwell RJA, Sato TA, Marvin KW, Mitchell MD (2003). Cytokines, prostaglandins and parturition-a review. Placenta. 24: S33-S46. https://doi. org/10.1053/plac.2002.0948.

-Khan HM, Mohanty TK, Bhakat M, Gupta AK, Tyagi AK, Mondal G (2015). Effect of vitamin E and mineral supplementation on biochemical profile and reproductive performance of buffaloes. Buffalo Bull. 34(1): 63-72.

- Kimura K, Goff JP, Kehrli Jr ME, Reinhardt TA (2002). Decreased neutrophil function as a cause of retained placenta in dairy cattle. J. Dairy Sci. 85(3): 544-550.

-Koracevic D, Koracevic G, Djordjevic V, Andrejevic S, Cosic V (2001). Method for the measurement of antioxidant activity in human fluids. J. Clin. Pathol. 54(5): 356-361. https://doi. org/10.1136/jcp.54.5.356.

- Eukaszewicz-Hussain A, Moniuszko-Jakoniuk J, Rogalska J (2007). Assessment of Lipid Peroxidation in Rat Tissues in Subacute Chlorfenvinphos Administration. Polish J. Environ. Stud. 16(2): 233-236.

- Marklund S, Marklund G (1974). Involvement of the superoxide anion radical in the autoxidation of pyrogallol and a convenient assay for superoxide dismutase. Eur. J. Biochem. 47(3): 469-474. https://doi.org/10.1111/j.1432-1033.1974. tb03714.

- Parmar SC, Parmar CP, Patel JA (2016). Use of pgf $2 \alpha$ in ovarian and uterine pathological conditions of bovine: a therapeutic approach. Explor. Anim. Med. Res. 6(2): 132-2141.

- Pontes GC, Monteiro PL Jr, Prata AB, Guardieiro MM, Pinto DA, Fernandes GO, Wiltbank MC, Santos JE, Sartori $R$ (2015). Effect of injectable vitamin $E$ on incidence of retained fetal membranes and reproductive performance of dairy cows. J. Dairy Sci. 98(4): 2437-2449. https://doi. org/10.3168/jds.2014-8886.

- Qu Y, Fadden AN, Traber MG, Bobe G (2014). Potential risk indicators of retained placenta and other diseases in multiparous cows. J. Dairy Sci. 97(7): 4151-4165. https:// doi.org/10.3168/jds.2013-7154.

-Robertson SA, Christiaens I, Dorian CL, Zaragoza DB, Care AS, Banks AM, Olson DM (2010). Interleukin-6 is an essential determinant of on-time parturition in the mouse.
Endocrinology. 151(8):3996-4006.https://doi.org/10.1210/ en.2010-0063.

- Saleh MA, Rateb HZ, Misk NA (2008). Comparison of blood serum proteins in water buffaloes with traumatic reticuloperitonitis and sequellae. Res. Vet. Sci. 85(2): 208213. https://doi.org/10.1016/j.rvsc.2007.11.007.

- Samanta S, Sharma A, Das B, Mallick AK, Kumar A (2016). Significance of Total Protein, Albumin, Globulin, Serum Effusion Albumin Gradient and LDH in the Differential Diagnosis of Pleural Effusion Secondary to Tuberculosis and Cancer. J. Clin. Diagn. Res. 10(8): BC14-18. https:// doi.org/10.7860/JCDR/2016/20652.8379.

-Shimizu T, Morino I, Kitaoka R, Miyamoto A, Kawashima C, Haneda S, Magata F (2018). Changes of leukocyte counts and expression of pro- and anti-inflammatory cytokines in peripheral leukocytes in periparturient dairy cows with retained fetal membranes. Anim. Sci. J. 89(9): 1371-1378. https://doi.org/10.1111/asj.13065.

- Srilatha K, Bobby Z, Subrahmanyam DK, NithinKumar U (2017). Insulin resistance and elevated C-reactive protein among first-degree relatives of ischemic stroke patients. Diabet. Metab. Syndr. 11 Suppl. 2: S873-S878. https://doi. org/10.1016/j.dsx.2017.07.008

- Tagesu A (2018). Review on the Reproductive Health Problem of Dairy Cattle. Dairy Vet. Scien. J. 5(1): 001-0012. https:// doi.org/10.19080/jdvs.2018.05.555655.

- Talukdar DJ, Talukdar P, Ahmed K (2016). Minerals and its impact on fertility of livestock: A review. Agric. Rev. 37(4): 333-337. https://doi.org/10.18805/ag.v37i4.6464.

-Tucho TT, Ahmed WM (2017). Economic and Reproductive Impacts of Retained Placenta in Dairy Cows. J. Reprod. Infertil. 8(1): 18-27. https://doi.org/10.5829/idosi. jri.2017.18.27.

-Williams HL, Johnson DJ, Haut MJ (1977). Simultaneous spectrophotometry of $\mathrm{Fe} 2+$ and $\mathrm{Cu}^{2+}$ in serum denatured with guanidine hydrochloride. Clin. Chem. 23(2): 237-240.

-Wischral A, Verreschi ITN, Lima SB, Hayashi LF, Barnabe RC (2001). Pre-parturition profile of steroids and prostaglandin in cows with or without foetal membrane retention. Anim. Reprod. Sci. 67(3-4): 181-188.

-Witt I, Trendelenburg C (1982). Gemeinsame Studie zur Erstellung von Richtwerten für klinisch-chemische Kenngrößen im Kindesalter. Clin. Chem. Lab. Med. 20(4): 235-242. https://doi.org/10.1515/cclm.1982.20.4.235.

- Yasuhara T, Koyama K, Sakumoto R, Fujii T, Naito A, Moriyasu S, Kageyama S, Hirayama H (2019). Enhanced glucocorticoid exposure facilitates the expression of genes involved in prostaglandin and estrogen syntheses in bovine placentomes at induced parturition. Theriogenology. 139: 1-7. https://doi.org/10.1016/j.theriogenology.2019.07.016.

•Yildiz H, ŞİMŞEK H, Saat N, YÜKSEL M (2011). Effects of dystocia on lipid peroxidation and enzymatic and nonenzymatic antioxidants in crossbred dairy cows. Bull. Vet. Inst. Pulawy. 55: 135-139.

-Young D (2001). Effects of disease on Clinical Lab. Tests, 4th ed AACC. 